\title{
Marcin Kanon
}

Uniwersytet w Białymstoku e-mail:m.kanon@o2.pl

ORCID: 0000-0003-3799-3459

DOI: 10.15290/mhi.2020.19.02.12

\section{Problematyczność stosowania metafizyki do pozytywizmu prawniczego na przykładzie tezy o społecznym źródle prawa}

\begin{abstract}
Abstrakt
Artykuł ma na celu przedstawienie pozytywistycznej tezy o społecznym źródle prawa w kontekście rozważań metafizyki klasycznej. Wykorzystano metodę analizy tekstów źródłowych i dokonano abstrakcji tez, które można uznać za metafizyczne. Twierdzenia metafizyczne, to twierdzenia egzystencjalne, a także esencjalne, które dany autor przyjmuje wprost, bądź są możliwe do rekonstrukcji na podstawie wniosków, które wyprowadza. Rozumowanie zostało oparte na przekonaniu, że uniwersalność metafizyki należy rozumieć również w aspekcie czasowym. Teza o zmienności sposobów rozumienia rzeczywistości, wraz z rozwojem ludzkości, jest jedną z kardynalnych założeń pozytywizmu w ogóle. W oparciu o to historiozoficzne prawidło, August Comte wyprowadza dalsze wnioski, co do filozofii możliwej na przyszłość. Negacja metafizyki prowadzi do niepogłębionego, być może nieświadomego, przyjęcia tez, które w historii filozofii zostały już opracowane. Przemyślenia zaprezentowane w niniejszym artykule zasadniczo skoncentrowane są na zagadnieniu sposobu bytowania społeczeństwa. Jego rozumienie warunkuje rozumienie faktów społecznych i na tej płaszczyźnie prowadzi do wniosków na temat społecznej źródłowości prawa. Główna część rozważań umiejscowiona została w kontekście historycznym, co pozwala dostrzec elementy trudno uchwytne współcześnie. Jednym z wniosków jest ustalenie, że metafizyka, wobec której pozytywizm występuje, jest tylko jednym z jej nurtów, który panował w XIX-wiecznej filozofii. Ze względu na brak szczegółowych opracowań zagadnienia, autor sygnalizuje problemy, rozpatrując je na poziomie ogólnym.
\end{abstract}




\section{Abstract \\ The problem of applying metaphysical explanation to legal positivism on the example of social source thesis}

The aim of this article is to present a legal positivist social source thesis in the context of classical metaphysical reflection. Author uses the method of analysing the source texts and abstracts theses that can be considered as metaphysical. Metaphysical theses divide into existential and essential. They are expressed directly by an author or possible to reconstruct. Reasoning was based on convenience that universality of metaphysics should be considered temporally. The thesis about the evolution of ways of understanding reality, along with the development of mankind, is one of the cardinal assumptions of positivism in general. Based on this historiosophical rule, August Comte draws further conclusions about a possible modern philosophy for the future. The denial of metaphysics leads to cursory, perhaps unconscious, acceptance of the theses that have already been developed in the history of philosophy. The reflections are essentially focused on the issue of ontological status of society. Its understanding determines the understanding of social facts and seems to have an impact on social source thesis. The main part of the reflection is placed in a historical context. It enables to examine some aspects that are difficult to consider nowadays. One of the conclusions is that metaphysics to which positivism opposes is dominant in $19^{\text {th }}$ century philosophy, but in general only one of many schools of thought. Since there is no specific literature on that matter, author signalize problems considering them generally.

Słowa kluczowe: pozytywizm, metafizyka, filozofia prawa, społeczne źródło prawa, August Comte

Key words: positivism, metaphysics, philosophy of law, social source thesis, August Comte

\section{Wprowadzenie}

Analiza twierdzeń składających się w pewien system, nieraz zmusza do wykroczenia poza ramy dziedziny, którą się zajmujemy. Dzieje się tak również dlatego, że nie znajdujemy, w granicach względnie spójnego systemu dziedziny naukowej, odpowiedzi na ogólniejsze pytania, tj. dotyczące przesłanek, z których wyprowadzamy wnioski szczegółowe. Kwestia ustalenia stopnia i granicy uogólnienia jest dyskutowana w filozofii, a bardziej szczegółowo w logice i ogólnej metodologii nauk. Poruszana jest przy okazji zagadnień istnienia i wzajemnego stosunku postawy dogmatycznej i krytycznej, a także próby posunięcia abstrakcji do granic możliwości. Chociaż w przeszłości często dyskredytowana, metafizyka wydaje się wciąż być ostatnią instancją odwoławczą dla twierdzeń nauk 
szczegółowych. Jednakże, poza wspólną nazwą "metafizyka”, przedsięwzięcia poznawcze określane tym terminem dzieli fundamentalna różnica. Dzieje się tak $\mathrm{m}$. in. dlatego, że przyjmując jedno z podstawowych stanowisk metafizycznych, z każdym kolejnym wnioskiem „oddalamy się” od innego możliwego stanowi$\mathrm{ska}^{1}$. Sytuacja taka wymaga w związku z tym każdorazowo analizy.

Nie inaczej ma się rzecz w filozofii prawa. Będąc najogólniejszą wśród dyscyplin prawniczych, chętnie korzysta z ustaleń filozofii ogólnej. Spośród dwóch kierunków filozoficznoprawnych: pozytywizmu prawniczego i prawa naturalnego, uzasadnień poprzez odwołanie się do metafizyki tradycyjnie spodziewać się można $\mathrm{w}$ ramach drugiego $\mathrm{z}$ wymienionych. Tymczasem $\mathrm{w}$ ostatnich latach, również $\mathrm{w}$ Polsce, próby tego rodzaju zdarzają się ze stanowiska pozytywizmu prawniczego ${ }^{2}$. Wydaje się, że przedsięwzięcie to, w zależności od sposobu rozumienia metafizyki, może być obarczone sporym ryzykiem doktrynalnym. W artykule niniejszym postaram się wykazać, że pozytywizm prawniczy nie może, bez zanegowania swoich kardynalnych założeń, odwoływać się do metafizyki. Na zagadnienie spojrzę z perspektywy metafizyki klasycznej. Przez przydawkę „klasyczna” rozumiem tradycję metafizyczną, czerpiącą źródłowo od Arystotelesa, pogłębioną i rozwiniętą przez mistrzów scholastycznych - głównie Tomasza z Akwinu, zjawiającą się następnie w postaci nurtu zwanego neoscholastyką ${ }^{3}$. Wydaje się, że spojrzenie na metafizyczne podstawy pozytywizmu prawniczego, z perspektywy współcześnie raczej mało popularnej, może przyczynić

1 W. Stróżewski, Ontologia, Kraków 2004, s. 19-34, 39-55. Z historycznego punktu widzenia dysponujemy trzema zasadniczymi terminami na określenie przedmiotu: filozofia pierwsza, metafizyka, ontologia. Różnice istnieją rzecz jasna również w poszczególnych nurtach. Na poziomie metafilozoficznym, analizy przedmiotowe na ten temat, zob. S. Maryniarczyk, Metafizyka a ontologie. Próby przezwyciężania metafizyki i ich paradoksy, Lublin 2015, s. 17-30. Bywa, że nie rezygnuje się z termi$\mathrm{nu}$ „metafizyka” nawet dla oznaczenia wysiłków intelektualnych datujących się od połowy XIX w. Zob. T. Czeżowski, O metafizyce, jej kierunkach i zagadnieniach, Kęty 2004, s. 50-73.

2 T. Gizbert-Studnicki, Metafizyka pozytywizmu prawniczego, „Prinicipia” 2015, t. LXI-LXII, s. 19-40. Dominacja pozytywizmu prawniczego prowadzi do uznania go za zasadę podziału współczesnej filozofii prawa na: „pozytywizm” i „non-pozytywizm”. Zob. T. Bekrycht, Metafizyka pozytywizmu prawniczego $w$ świetle fenomenologii prawa, „Avant. The Journal of the Philosophical-Interdisciplinary Vanguard" 2018, t. 9, nr 1, s. 21-29. Artykuł polemiczny, naświetlający podstawowe tezy pozytywizmu prawniczego z punktu widzenia fenomenologii prawa. Zob. także Sz. Mazurkiewicz, Legal Positivism Social Source Thesis and Metaphysical Grounding: Employing Metaphysical Grounding Based on Metaphysical Laws, „Archiwum filozofii prawa i filozofii społecznej” 2019, nr 2, s. 5-19. Jest to próba sięgnięcia do metafizyki, celem uzasadnienia tezy o społecznym źródle prawa, na wybranych przykładach z anglojęzycznego kręgu kulturowego.

3 Przykładowo, w podręczniku światowej sławy do filozofii neoscholastycznej, termin „metafizyka ogólna” jest zastępowany terminem „ontologia”. Definicja filozofii jest następująca: Philosophia est scientia rerum ratione humana cognoscibilium per causas vel rationes ultimas naturali lumine comparata. Ontologia zaś, to scientia entis considerati sub rationibus eius maxime communibus. Istotna jest uwaga leksykalna, jaka poczyniona zostaje w odniesieniu do terminu „metafizyka”. Jego brzmienie od razu nasuwa na myśl obiekty ponadnaturalne, „ponad-fizyczne”. Dlatego też czyni się rozróżnienie na metafizykę generalis et spcialis. Zob. S. Reinstadler, Elementa philosophiae scholasticae, Fryburg Bryzgowisjki 1901, s. 1-4, 207-208. 
się do głębszego zrozumienia problematyki tego, co nazywamy uzasadnieniem metafizycznym. Jednym $\mathrm{z}$ podstawowych założeń, jakie towarzyszy analizie z przyjętego punktu widzenia, jest twierdzenie o obecności założeń metafizycznych w każdym stanowisku filozoficznym. Chodzi o niezależność metafizyki od sfery wolicjonalnej człowieka - w tym przypadku badacza, filozofa.

Na pewnym etapie abstrakcji, umysł nie może przejść bezkrytycznie wobec kwestii zasadniczych, metafizycznych właśnie. Pozytywizm, sformułowany przecież jako doktryna już w pierwszej połowie XIX w., ufundowany jest na konkretnych metafizycznych podstawach. Wydaje się, że mimo deklaracji Comte’a w tym zakresie, nowej metafizyki nie należy wcale tworzyć, lecz przyjrzeć się tej, jaka leży u podstaw tegoż nurtu, z perspektywy jej historycznego rozwoju.

Studiowanie historii pozytywizmu paradoksalnie prowadzi do wniosku, że coś takiego jak „pozytywizm”, poza samym terminem, zasadniczo nie istnieje. Ponadto, nazwa doktryny okazuje się nieodpowiednia, jako że zdecydowana większość tez, w tym sztandarowe, mają charakter negacyjny. Interesujące $\mathrm{w}$ związku z tym wydaje się to, czy podobna sytuacja ma miejsce w naukach prawnych. Aby przeprowadzić tego rodzaju analizę, konieczne jest uzasadnienie następujących intuicji:

1) Pozytywizm prawniczy, w zasadniczych twierdzeniach metafizycznych, jest związany z ogólnym nurtem pozytywizmu.

2) Historyczny podział pozytywizmu na: francuski (kontynentalny) - szkoła A. Comte’a, E. Littre’a; i angielski (utylitarno-analityczny) - głównie D. Hume, J. S. Mill i H. Spencer; znajduje swoje odzwierciedlenie w filozofii pozytywizmu prawniczego: kontynentalnego i analitycznego.

3) Stosunek pozytywizmu, a także filozofii pozytywnej, do filozofii i metafizyki w historycznym rozumieniu, daje się przełożyć na stosunek pozytywizmu prawniczego do tychże dziedzin.

Poruszana problematyka jest odległa czasowo, dlatego też literatura, do której się odwołam, poza współczesnymi odniesieniami, musi sięgać mniej więcej przełomu XIX i XX w. Poszukiwanie odpowiedzi u autorów publikujących w czasie, kiedy zagadnienia te były „żywe”, pozwala uniknąć dogmatyzmu towarzyszącego pracom powstałym w późniejszym czasie ${ }^{4}$. Po drugie, możliwe jest tym sposobem spojrzenie na tezy pierwotne, które z czasem naturalnie uległy uszczegółowieniu, wydając szereg pomniejszych szkół, których analiza wyma-

4 Przykładowo, podczas gdy współcześnie mamy do czynienia $\mathrm{z}$ uprawianą na szeroką skalę socjologią - również w ogólnych naukach o prawie, to w czasie publikacji rozpraw Augusta Comte’a, nie było wcale oczywiste, że przedsięwzięcie to ma rację bytu. Polemizowano z tego rodzaju poglądem, co do zasadności metodologicznej i metafizycznej właśnie. Dogmatyzmu nie rozumie się zatem potocznie, jako zarzutu braku refleksyjności, lecz metodologicznie, jako wyprowadzanie wniosków, z poprzednio przyjętych ogólnych metafizycznych założeń (na temat istnienia i struktury bytów) których już się później nie udowadnia. 
ga obszernego studium. Prześledzę kolejno podstawowe twierdzenia metafizyczne pozytywizmu i postaram się przedstawić zasadnicze różnice, jakie dzielą pozytywizm francuski i angielski. Następnie przeniosę ustalenia na grunt tzw. pozytywizmu prawniczego i dokonam rekonstrukcji podstawowych twierdzeń metafizycznych, jakie tam spotykamy. Podsumowując, postaram się wykazać, że metafizyka jest w obu nurtach obecna. Możliwość jej dostrzeżenia wymaga jednak oparcia się na wspomnianej klasycznej linii rozwojowej tejże dziedziny. Z tego punktu widzenia, nowożytny zwrot antymetafizyczny okazuje się zasadniczo przeciwny metafizycznemu tłumaczeniu fizyki, bez szkody dla samej metafizyki. Mamy raczej do czynienia z błędem polegającym na odczytaniu twierdzenia metafizycznego, jako fizycznego, a tym samym kategorialnego przesunięcia, które rzeczywiście będąc błędne, wywołało silną reakcję „anty - metafizyczną”" Analiza zagadnienia $\mathrm{z}$ tej perspektywy pozwala wyciągnąć doniosłe wnioski w zakresie problematyki metafizycznej w pozytywizmie, a co ważniejsze, przedstawia spór prawo naturalne - pozytywizm, w nieco innej perspektywie niż zazwyczaj spotykana.

\section{Pozytywizm a filozofia i metafizyka}

Rekonstrukcja metafizycznych podstaw danego kierunku, czy też prądu myślowego, nie jest zadaniem prostym. Wynika to ze statusu samych zagadnień, a także stosowania różnych metod do ich rozpatrywania. Tak jest w przypadku pozytywizmu, który z pewnością nie należy do szkół łatwo dających się scharakteryzować. Trudność ta może wynikać albo z niejasnego opracowania zagadnienia przez autorów uznawanych za sztandarowych: Comte, Littre, a w Anglii: Hume, Mill i Spencer, albo też niejasności powstałych na etapie interpretacji myśli źródłowej. Jako konkretny przykład możemy podać rozumienie pozytywizmu logicznego, kiedy to podstawowe twierdzenie metafizyczne - o badaniu faktów, uzupełnione jest stosowaniem metody analizy pojęciowej ${ }^{6}$. Rozróżnienie na przedmiot i metodę, wymaga uzasadnienia metafizycznego. Problematyczne będzie tu właśnie różnicowanie i jego racja, a zatem chociażby problem przedmiotowości i podmiotowości istnienia tegoż podziału. Nie wchodząc w kwestię uzasadnienia tak głęboko, możemy stwierdzić, że stojąc na powyższym stanowisku, musimy założyć, że istnieją fakty (sąd egzystencjalny) i są one badane przy pomocy określonej metody, którą jest analiza pojęciowa (sąd epistemologiczny). Wynika z powyższego, że analiza dotyczy pojęć. Pytanie, które

5 Z. Ogonowski, Filozofia szkolna w Polsce XVII wieku, Warszawa 1985, s. 5-6. Praca ta jest przykładem respektowania różnicy między filozofią przyrody i filozofią w ogóle, której trzonem jest metafizyka. Podczas gdy aplikacja tez Arystotelesa do nauk przyrodniczych, wraz z ich rozwojem, nie mogła się ostać, to metafizyka mogła funkcjonować nadal. Brak rozróżnienia między dwoma dyscyplinami i sposobami rozumowania zdaje się ciążyć na opinii na temat metafizyki, aż do dzisiaj.

6 T. Gizbert-Studnicki, op. cit. s. 20. 
można w tym przypadku określić jako metafizyczne brzmi: czym są fakty, które pozytywizm logiczny bada i w jaki sposób je poznajemy? Po drugie, jakiego rodzaju relacja zachodzi między zbadanymi pojęciami a faktami? Czy fakty to tyle, co rzeczy, czy potrzebne jest również uzasadnienie ich wzajemnego stosunku?

Inne zdanie na ten temat usłyszymy ze strony pozytywizmu kontynentalnego (francuskiego), przynajmniej tego w wydaniu Augusta Comte’a. Być może zatem inne twierdzenie metafizyczne leży u jego podstaw. Odczytywany jako opozycja w stosunku do niemieckiej filozofii idealistycznej XIX w., nie pozwala na zamknięcie poznania $w$ sferze podmiotowej ${ }^{7}$. Można odnieść wrażenie, że w związku z tym nie o przedmiotową różnicę przedstawicielom pozytywizmu chodzi, lecz o metodę, czy też pewien postulat interpretacyjny, skoro nie jest przyczyną niezgody fakt, że w zasadzie badane są dwie różne rzeczy. Interesujące, że w ramach jednego nurtu, istnieje już na wstępie różnica tak zasadnicza. $\mathrm{W}$ ten sposób stajemy przed jednym $\mathrm{z}$ najbardziej dyskutowanych problemów filozoficznych, tj. zagadnieniem przedmiotu ludzkiego poznania. Już na początkowym etapie analizy pozytywizmu, dochodzimy do wniosku, że „pozytywizm” to zasadniczo wspólna $\mathrm{n}$ a $\mathrm{z} \mathrm{w}$ a, dla różnych przedsięwzięć. Aby uniknąć pomieszania, o które w takiej sytuacji nietrudno, posługiwał się będę terminami: „pozytywizm francuski” i „pozytywizm angielski”.

Pozytywizm francuski, nastawiony jest na badanie rzeczywistości obiektywnej, dlatego też szuka właściwego obiektu badanego „poza” podmiotem. Nie zadowala się przedstawieniem wewnętrznym, ujęciem poznawczym - pojęciem. Potrzebuje istnienia rzeczy i praw, które właśnie bada. W tym też znaczeniu jest doktryną antymetafizyczną, co jednak wymaga uszczegółowienia. Pozytywizm angielski jest u zarania podmiotowy. W związku z długą tradycją krytyczną, na Hume’a jako inspiratora i bodziec dla własnych poszukiwań powoływał się przecież Kant, staje przed problemem zgodności poznania z rzeczywistością ${ }^{8}$. W związku z zanegowaniem możliwości dotarcia do rzeczy, wykrycia ich istoty, skupia się na tym, co bez wątpienia jest nam dane - ujęcia podmiotowe (pojęcia). Jako wyrażane w języku, zwracają uwagę na sam język, który w ten dopiero sposób staje się samodzielnym, w sensie metodologicznym, przedmiotem badania. $\mathrm{Na}$ „zewnętrzne” nastawienie pozytywizmu francuskiego i „wewnętrzne” angiel-

7 F. S. Krupiński, Szkoła pozytywna, Oddruk z Bibl. Warsz. z m. lipca, sierpnia i września 1868, s. 14. Autor sprzyja omawianej szkole, widząc w niej receptę na, jego zdaniem, powszechny subiektywizm w filozofii tamtego czasu. Uważa pozytywizm za stary nurt, którego jednym ze stanowczych wyrazicieli miałby być August Comte.

8 Związki filozofii analitycznej z myślą Kanta, których wspólnym rdzeniem wydaje się być sceptycyzm metodologiczny Hume’a, możemy odnaleźć u współczesnych przedstawicieli szkoły analitycznej. W tym nurcie zob. P. Strawson, Analiza i metafizyka, Kraków 1994, s. 9, 44-45, 64. Na tym etapie rozwoju, jako nie mniej ważne niż poznawcze cele filozofii, wskazuje się również jej właściwości metodologiczne - precyzujące, a nawet terapeutyczne. 
skiego, zwraca uwagę również metoda stosowana w dziedzinie psychologii. Jest to bardzo istotne $\mathrm{z}$ punktu widzenia materialistycznego podłoża doktryny. Psychologia dla Comte'a, to przede wszystkim biologia i fizjologia, podczas gdy dla Anglików celem jest zbadanie narzędzia, a zatem wniknięcie w podmiotowość - analiza introspektywna9.

Stwierdzenie, że przedmiotem poznania są pojęcia, jest skonkretyzowanym stanowiskiem filozoficznym, które daje początek wielu dziedzinom poznawczym. Różni się zasadniczo od twierdzenia, że rzeczy (świat) badamy przy pomocy pojęć. W pierwszym przypadku mamy do czynienia, w skrajnej wersji, ze stanowiskiem monizmu idealistycznego, natomiast w drugim, jako właściwą metodę dotarcia do świata pozapodmiotowego wskazuje się namysł nad podmiotowymi ujęciami poznawczymi. Samo przejście, sposób ujęcia, adekwatność poznania i rzeczywistości, na tym etapie nie są szczegółowo badane ${ }^{10}$. Pojęcia komunikowane są przy pomocy języka. Są również zawsze myślane w jakimś języku, choć wydaje się, że to twierdzenie jest ryzykowane ${ }^{11}$. Nie jest specjalnie zaskakujące, że pierwszym przedmiotem badania, aby nie „metafizykować” za wiele, uczyniono właśnie język. Inaczej przedstawia się sytuacja w przypadku absolutyzacji tegoż poglądu, który łączy się z zanegowaniem możliwości „dotarcia do rzeczy”, czy też jej „istoty”, a tym samym zanegowania metafizyki w klasycznym znaczeniu. Z tego punktu widzenia pozytywizm angielski zajmowałby określone stanowisko względem rzeczywistości i to byłoby właśnie jedno z poszukiwanych twierdzeń metafizycznych. Dla dostrzeżenia, że czym innym jest sposób poznawania (metoda) i przedmiot poznawany, posłużyć się możemy odróżnieniem kryterium statycznego i dynamicznego. Pozytywizm angielski jako metoda, byłby ujęciem dynamicznym i znaczyłby tyle, co sposób postępowania badacza. W znaczeniu statycznym mielibyśmy do czynienia $\mathrm{z}$ efektami tego wysiłku, które nie mogą być tym samym, co metoda. Widzimy ponownie, że „metafizykę” jednego i drugiego pozytywizmu łączy w głównej mierze nazwa. Wspólne są kierunek i cel. Zasadniczo wspólna jest również metoda, choć nawet w tym zakresie występują różnice.

9 Opracowanie tych zagadnień i zwrócenie uwagi na różnicę, jaka leży między dwoma pozytywizmami w zakresie psychologii, zob. S. Pawlicki, Studya nad pozytywizmem, Warszawa 1886, s. 110. Poza tym jest to praca przedstawiająca pozytywizm z każdej możliwej strony, łącznie z biogramami sztandarowych postaci tego nurtu.

10 H. Taine, Filozofia pozytywna w Anglii. Studyum nad Stuartem Millem, Warszawa 1883, s. 59, 63, 65. Autor przedstawia sposób rozumienia metody badawczej i podłoża empirycznego systemu Mill'a. Nie przekreśla metafizyki, jednak wyznacza jej węższy zakres i wiąże z ustaleniami empirycznymi. Silny związek z zasadą przyczynowości i nowożytnym jej rozumieniem, przedefiniowaniem, jest kolejnym wyróżnikiem pozytywizmu w Anglii.

11 M. Zirk-Sadowski, Analityczna filozofia prawa, [w:] Filozofia prawa. Normy i fakty, red. J. Hołówka, B. Dziobkowski, Warszawa 2020, s. 49. 
W uproszczeniu, z puntu widzenia klasycznego, ustalenia metafizyczne będą podstawą (niekoniecznie pierwotną czasowo) dla twierdzeń szczegółowych. Można zatem wygłosić twierdzenie w ogóle nie zastanawiając się nad tym, w jaki sposób jest ono uzasadnione metafizycznie. Co więcej, można otwarcie zająć stanowisko anty-metafizyczne. W obu przypadkach będzie to jednak czynność istniejąca po stronie podmiotu. Dopiero przy absolutyzacji podmiotowości, tzn. zanegowania dualizmu (przedmiot - podmiot), można wyprowadzić wniosek o tym, że metafizykę można „pominąć”. Jest to zasadnicza różnica, która rzutuje na dalszą interpretację.

W założeniach pozytywizmu francuskiego, metafizykę trzeba będzie konstruować, syntetyzować $\mathrm{z}$ faktów szczegółowych ${ }^{12}$. Jest zatem operacją dokonywaną na materiale empirycznym, poddanym analizom wymagającym ścisłości naukowej. Jeśli tak, to nie mogła metafizyka istnieć, dopóki nie istniała pozytywna wiedza ścisła, pozwalająca na dostarczenie rzetelnych danych. $Z$ tego punktu widzenia, wszelkie wcześniejsze przedsięwzięcia są spekulacją, w pejoratywnym tego słowa znaczeniu. Dodatkowo, z punktu widzenia filozofii pozytywnej Comte’a, były słusznie minionym etapem rozwoju ludzkości. Nastawienie empiryczne jest cechą wspólną z pozytywizmem angielskim, jednak zachodzą w tym względzie pewne różnice ${ }^{13}$.

Już na tym etapie możemy dostrzec, że próbując metafizycznie uzasadnić stanowisko pozytywistyczne - to ogólne, jak i prawnicze (w zakresie, w jakim są zbieżne), mamy do czynienia z różnymi poziomami uzasadnienia. Jeśli punktem wyjścia w pozytywizmie jest określony przedmiot badań i metoda, które nadto są umiejscowione w historycznym rozwoju ludzkości, to mamy do czynienia faktycznie ze stosunkowo wąskim stanowiskiem poznawczym, które jest już fundowane na założeniach metafizycznych. $Z$ punktu widzenia metafizyki klasycznej, sytuacja taka może zostać paradoksalnie odczytana jako dogmatyzm ${ }^{14}$.

12 Taką rolę, nie metafizyce, jako że w pozytywizmie ma ona swoiste, historiozoficzne znaczenie, lecz filozofii, wyznaczał już August Comte. Metafizyka rozumiana jest, z punktu widzenia filozofii pozytywnej, jako konieczny w swoim czasie, lecz już miniony, sposób rozumienia rzeczywistości, charakterystyczny danemu etapowi dziejowego rozwoju ludzkości. Bliżej jej do etapu teologicznego niż pozytywnego, jest jednak postępem w stosunku do pierwotnych sposobów poznawczych. Zob. A. Comte, Rozprawa o duchu filozofji pozytywnej, Warszawa 1936, s. 1-2.

13 H. Taine, op. cit, s. 79-80. „Mojem zdaniem tworzą dwie te czynności, epirya i abstrakcya, całą potęgę ludzkiego umysłu. Pierwsza jest z dążnością praktyczną, druga ze spekulatywną. Pierwsza bada naturę, jako sieć zjawisk, druga jako system praw; pierwsza jest metodą angielską, druga niemiecką". Rozważania na temat przedmiotu metafizyki przed pozytywizmem, zob. T. Czeżowski, op. cit., s. 47.

14 Sam Comte nie odżegnuje się od dogmatyzmu. Kilkakrotnie podkreśla, że wnioski wyprowadzane $\mathrm{z}$ doświadczenia formułowane są, przykładowo, „(...) na mocy powszechnego dogmatu o niezmienności praw przyrody". Zob. A. Comte, op. cit, s. 20. Pojęcie dogmatyzmu jest rozumiane różnie. Wydaje się, że w pozytywizmie ma ono znaczenie również inne niż naukowe, czy poznawcze. 
Upraszczając, celem wyjaśnienia pojawiającej się trudności, można powiedzieć, że to, co w pozytywizmie jest punktem wyjścia, w metafizyce klasycznej jest jednym z możliwych punktów dojścia. Perspektywa pozytywistyczna byłaby w związku z tym nad wyraz wąska, co zresztą pełni istotną rolę w jednym ze stawianych wymogów - pewności wiedzy. Słuszności tej interpretacji dowodziłby również częsty zarzut stawiany w stosunku do pozytywizmu, że jest on doktryną jedynie formalną.

Być może należałoby odróżnić problem metafizyczny, od zajęcia względem niego konkretnego stanowiska. Wychodząc od dualizmu poznania (podmiot przedmiot), można wyszczególnić od razu trzy podstawowe stanowiska, jakie możemy zająć. Pierwsze dawałoby prym podmiotowi, drugie przedmiotowi, natomiast trzecie można byłoby określić, jako podmiotowo - przedmiotowe. Nie wartościując żadnego z nich, można stwierdzić, że zajęcie któregokolwiek i wyprowadzenie $\mathrm{z}$ niego dalszych wniosków, jest czynnością intelektualną innego poziomu niż zastanawianie się nad zasadnością samego tego podziału. $\mathrm{W}$ ten sposób można by wytłumaczyć ową nieusuwalność metafizyki. Fakt nieporuszania zagadnienia sposobu ludzkiego poznania (ignoramus), nie powoduje jego nieistnienia. Przeciwnie, stanowisko metafizyczne obecne byłoby zawsze, lecz sformułowane nie wprost. Jeśli tak jest, to negacja metafizyki poskutkować może doniosłymi uchybieniami, które rzucają cień na cały system.

Podsumowując, pozytywizm, jako nurt funkcjonujący w literaturze filozoficznej pod tą nazwą, jest przede wszystkim metodą ${ }^{15}$. Wyjaśnia to trudności związane z pogodzeniem wspominanych pierwotnych rozbieżności metafizycznych w pozytywizmie francuskim i angielskim. Postuluje się niewyznaczanie przedmiotu a priori, lecz stosując metodę oczekuje się wyników poznawczych. Dopiero na tak wypracowanym materiale można pokusić się o syntezę i próbę czegoś, co można określić filozofią pozytywną. Wspólną cechą jest niewątpliwie nieprzychylny, mówiąc delikatnie, stosunek do metafizyki i postawa podejrzliwa względem filozofii w ogóle. Uchwycenie zasadniczych momentów tejże postawy, możliwe jest u jej źródła, tj. w myśli jej ortodoksyjnych przedstawicieli. Doktryna ulega dalszemu rozwojowi, różnicując się coraz bardziej. Będąc w postawie antymetafizyczna, utrudnia tym samym dostrzeżenie podstawowych założeń, na których jest fundowana, dlatego wymaga każdorazowo ich odkrycia.

Tymczasem, dokonując analizy ze stanowiska klasycznego, metafizyka jest czymś koniecznym, w zasadzie nieusuwalnym, a dodatkowo pierwotnym ${ }^{16}$.

15 K. Kaszewski, Pozytywizm, jego metoda i następstwa, b.d., s. 3-5. Autor twierdzi, że pozytywizm, mimo iż sam odżegnuje się od tej nazwy, poza metodą, jest również systemem.

16 Do wniosków takich można dojść również podczas analizy skrajnie antymetafizycznych kierunków, jak pozytywizm logiczny. Zob. M. Firlej, Założenia metafizyczne w programie pozytywizmu logicznego, „Hybris” 2016, nr 35B, s. 31-48. 
Skoro tak, to wszelka próba rezygnacji z niej znaczyłaby tyle, co w ogóle zagadnień tych nie poruszać - wspominane ignoramus ${ }^{17}$. Byłby to po prostu postulat: jeśli chcesz być pozytywistą, postępuj tak, jakby metafizyka nie istniała. Należy pamiętać, że negacja metafizyki w pozytywizmie jest, po pierwsze, negacją pewnej fazy rozwoju ludzkości (nie człowieka), a zatem towarzyszących jej metod. Jako taka wynika z wizji historiozoficznej Comte’a i jest w zasadzie dowolna. Po drugie, metafizyka jako metoda zostaje odrzucona, co wiąże się z utożsamianiem jej, ogólnie i nieco krzywdząco, z filozofią idealistyczną - głównie niemiecką. Ta bowiem nie spełnia wymogu obiektywności, jako że zamyka całe poznanie $\mathrm{w}$ sferze podmiotowej. Dopuszczalne jest za to istnienie filozofii pozytywnej, czyli syntezy twierdzeń nauk szczegółowych. Co ważne, sam Comte prawdopodobnie nie znał dzieł Kanta, jak zresztą w ogóle mało był zorientowany w filozofii. Czytając przywoływaną pracę ojca pozytywizmu, nie uzyskamy odpowiedzi na pytanie, o jaką metafizykę, w historycznym rozwoju, autorowi chodziło. Zasadniczo poruszane są tylko teleologiczne zapatrywania i personifikacje dokonywane na niższych szczeblach rozwoju ludzkości. Nie jest przesadą stwierdzenie, że takie zapatrywanie świadczy o braku głębszego wniknięcia w zagadnienia.

\section{Metafizyczne tezy pozytywizmów z punktu widzenia metafizyki klasycznej}

Mając na uwadze powyższe trudności w rekonstrukcji pozytywizmu, traktując sprawę z punktu widzenia całościowego historycznego rozwoju metafizyki, odpowiedź na pytanie o jej obecność w pozytywizmie, będzie twierdząca. Co warte ponownego podkreślenia, dopiero w klasycznym naświetleniu pozytywizm przedstawia się jako doktryna osadzona na konkretnych założeniach. Wydaje się, że u podstaw pozytywizmu francuskiego, w sformułowaniu pierwotnym, a zatem pozytywizmu ortodoksyjnego, leży metafizyka przyjmująca:

a) ewolucyjne rozumienie rzeczywistości, jako procesu zmiany; wydaje się, że mimo negacji celowości - celowościowe ${ }^{18}$;

b) postulowaną tylko rezygnację $\mathrm{z}$ doszukiwania się celowości na rzecz poszukiwania związków między obserwowanymi zjawiskami ${ }^{19}$;

17 Warto ponownie zauważyć, że nie polepsza sytuacji fakt, że ojcowie założyciele pozytywizmu, przez metafizykę rozumieją właśnie filozofię podmiotu - idealizm niemiecki, zwłaszcza wyrastający z filozofii Kanta. Zob. K. Kaszewski, op. cit., s. 6. Uzasadnienie tego, że metafizyka w pozytywizmie istnieje zob. s. 19-21. Jest to wynik raczej popularności pewnych prądów myślowych niż rzetelnej analizy historycznej, jako że równolegle istniało przecież wiele konkurencyjnych nurtów, by wymienić tylko scholastykę (neo-scholastykę), kształtującą się fenomenologię, czy motywowany nowymi, jak na owe czasy, zdobyczami nauk przyrodniczych - monizm w odsłonie materialistycznej.

18 A. Comte, op. cit., s. 2-14. U swojego celu rozwój ma zatrzymać się na fazie racjonalnego pozytywizmu. Pozostałe etapy są nieodwracalnie minione, aczkolwiek były konieczne.

19 Ibidem, s. 15. 
c) niezmienność praw przyrody i opierając się natych prawach podejmująca próby przewidywania przyszłości ${ }^{20}$, a także, co okaże się nieco później:

d) prymat całości nad częścią, a zatem zbiorowości nad jednostką.

Dodatkowo, Comte absolutyzuje przyjętą metodę, głosząc jej stosowalność do wszelkich zjawisk i każdej z dziedzin. W tej myśli ma źródło, trwający zdaje się do dzisiaj, spór o naukowość humanistyki. Co interesujące, a okaże się fundamentalne w dalszej części wywodu, rozumowanie Comte’a skłania się raczej w kierunku gatunkowym, zbiorowym. Ewoluuje rzeczywistość, a nie jej elementy. Istnieje część, ponieważ istnieje całośćc ${ }^{1}$. Wszystkie te założenia, nie mniej niż na nauki przyrodnicze, rzutują na humanistykę, którą coraz chętniej będzie zastępować perspektywa społeczna. Historycznym założycielem socjologii jest właśnie August Comte.

Pozytywizm angielski stawia u podstaw tezę metafizyczną podmiotową. Oznacza to, że problem podmiot - przedmiot poznania, rozstrzyga na korzyść tego pierwszego. Bada pojęcia, a więc jednostkowe akty poznawcze. Komunikowalność pojęć, a zatem ich poznawalność, a może sam proces myślenia, odbywa się w języku i to właśnie język, lecz już po tzw. zwrocie lignwistycznym, jest bytem, który tradycja analityczna bada. Tym samym uwzględniamy w jakiejś części wymóg empiryzmu. Mniejszy jest zatem nacisk na „wychodzenie poza” podmiot, celem weryfikacji danego twierdzenia. Częściej spotkamy za to rozkładanie pojęć na czynniki pierwsze, precyzowanie pewnych twierdzeń i próby klarowniejszego przedstawienia analizowanych zagadnień. Wydaje się, że stanowisko pozytywizmu angielskiego, z punktu widzenia metafizyki klasycznej, jest obszerniejsze i bardziej metodyczne niż stanowisko pozytywizmu francuskiego. Świadczyć o tym może również trudność w wyprowadzeniu konkretniejszych twierdzeń, takich np. jak w przypadku scharakteryzowanych powyżej tez Comte' a. Zdarza się jednak, że towarzyszy mu niekonsekwencja, która nie jest oceniana negatywnie ${ }^{22}$. Jeśli wyróżniamy medium - język, którego badanie ma umożliwić dotarcie do rzeczywistości, to należałoby również uzasadnić, w jaki sposób zachodzi adekwatność między tym, co pośredniczy a tym, co jest pośredniczone.

Jeśli zapytamy o metafizykę, wobec której pozytywizm angielski protestuje, to wydaje się, że chodzi o jedną z odmian wersji scholastycznej z jej schyłkowego

20 Ibidem, s. 20.

21 Ibidem, s. 20, 87.

22 M. Zirk-Sadowski, Pozytywizm prawniczy a filozoficzna opozycja podmiotu i przedmiotu poznania, [w:] Studia z filozofii prawa, red. J. Stelmach, Kraków 2001, s. 85. Rekonstrukcja pojęciowa jest w tym przypadku wtórna wobec zewnętrznego przedmiotu poznania. Uwaga ta dotyczy propozycji J. Austina. 
okresu (XIV-XV w.), która utożsamiała twierdzenia fizyczne z metafizyczny$\mathrm{mi}^{23}$. Bardziej szczegółowe określenie jest trudne, jako że autorzy stosują zbiorową nazwę, dla kilkusetletniego okresu myśli ${ }^{24}$. W pracy Comte’a scholastyka pojawia się jako nacechowany negatywnie stereotyp. Także i w tym przypadku historyczna identyfikacja jest utrudniona. Warto podkreślić, że oba nurty powstały po Kartezjuszu. Stanowisko dualistyczne, najprawdopodobniej rozumiane jest tak samo jak, bądź analogicznie do res extensa i res cogitans. Problemy teoriopoznawcze, to problemy, które przedstawił Kartezjusz. Perspektywa metafizyki klasycznej, jako datującej się nieprzerwanie od starożytności, jest zatem znacznie szersza.

\section{Pozytywizm prawniczy}

Przekładając ustalenia z poprzedniego punktu, na grunt filozofii prawa, mielibyśmy do czynienia z analityczną filozofią prawa, jako odpowiednikiem pozytywizmu angielskiego, i socjologią prawa, jako odpowiednikiem pozytywizmu francuskiego. Termin „filozofia prawa” pełni współcześnie rolę łącznika nieraz dla skrajnie różnych zapatrywań. Jako zbyt ogólny, jest trudno diagnostyczny. Związek tez pozytywizmu ogólnego z pozytywizmem prawniczym, rodzi liczne problemy, jako że funkcjonuje przecież w środowisku naukowym sztandarowy termin „pozytywizm prawniczy”, który sugeruje, że to właśnie w jego kierunku należy skierować poszukiwania. $Z$ analiz ogólnych pozytywizmu wynika jednak, że pod terminem tym kryje się zasadniczo bardzo niewiele cech wspólnych obu kierunkom ${ }^{25}$. Rzecz jasna ujęcie takie wydać się może bezpodstawne, $\mathrm{z}$ uwagi

23 M. Zirk-Sadowski, Pozytywizm prawniczy..., s. 84. Wydaje się, że w filozofii prawa, jako zdominowanej przez spór pozytywizm - prawo natury, opozycja metafizyczna to opozycja wobec metafizyki, na której twierdzenia budują koncepcje prawnonaturalne. Trudno uznać, że opierają się na jednej jej wersji, dlatego każdorazowo należy analizować, o jaką metafizykę chodzi. Zadanie to wykracza poza ramy niniejszego opracowania.

24 H. Taine, op. cit., s. 63. „Siłę, materyą i inne pojęcia nowoczesnej metafizyki mamy za naleciałości nauki scholastycznej. Nie postrzegamy nic nad zjawiska i prawa rządzące niemi, czyli skutki i ich wzajemny związek i twierdzimy z wami, że wszelka wiedza zasadza się przedewszystkiem na łączeniu i spajaniu faktów". Wydaje się, że w twierdzeniu powyższym przyjmuje się fizyczne rozumienie materii, a nie metafizyczne. Stąd można się domyślać, że scholastyka, jako szkoła filozoficzna (nie teologiczna ani przyrodnicza), była pozytywistom niekoniecznie znana.

25 Zob. Leksykon współczesnej teorii i filozofii prawa, red. J. Zajadło, Warszawa 2007, s. 12-13, 313-315. Zarówno socjologia prawa, jak i analityczna teoria prawa, traktowane są jako odmiany pozytywizmu prawniczego. Por. Wprowadzenie do nauk prawnych. Leksykon tematyczny, red. A. Bator, Warszawa 2012, s. 13-15, 41-43. W przypadku analitycznej teorii prawa mamy do czynienia wybitnie z m e t o d ą analizy wypowiedzi językowych (metafizyczne założenie pozytywizmu angielskiego). Jeśli chodzi o socjologię prawa, to pomijając problematykę relacji dyscyplinarnych, autor podkreśla jej empiryczne nastawienie (owa zewnętrzność) i nastawienie na odnajdywanie praw społecznych. Dostrzegamy zatem daleko idącą zbieżność ustaleń współczesnych z historycznym odtworzeniem zaprezentowanym w niniejszym artykule, z punktu widzenia filozofii ogólnej. Nie wydaje się przesadą twierdzenie, że z punktu widzenia filozofii ogólnej, pozytywizm prawniczy jest nazwą 
na ogromną różnorodność w ramach pozytywizmu prawniczego i kierunków prawno-naturalnych, jednakże zarzut ten dotyczy każdego, kto o „pozytywizmie”, czy „prawie natury” pisze ${ }^{26}$. Na podstawie przeciwstawienia: pozytywizm - prawo natury, może dostrzec istotne analogie. Widoczne jest to zwłaszcza w momencie pojawienia się konieczności uzasadnienia prawa, przez odwołanie się do innych bytów.

Teza o społecznych źródłach prawa przedstawiana jest w kontekście sporu, jaki toczy się w filozofii prawa między kierunkami prawno-naturalnymi i pozytywistycznymi. Takie postawienie sprawy wymaga jednak doprecyzowania. Fakt istnienia sporu jest przecież wtórny wobec podstawy, czy głównego twierdzenia, które niezgodę wywołało. Zwrócenie uwagi na rolę przypisywaną moralności i skojarzenie z nią metafizyki jest intuicją słuszną w zakresie, w jakim dla nieoficjalnych norm (niepopartych autorytetem państwa), poszukuje się uzasadnienia. Powoduje jednak zawężenie sporu do tego właśnie zakresu, co utrudnia poszukiwania podstaw konfliktu ${ }^{27}$. Sam kierunek rozumowania mówi bardzo dużo, jako że pozwala dostrzec, iż przez „metafizyczność” pozytywizm rozumie w tym przypadku próbę oparcia zasad i reguł poza społeczeństwem, a ostatecznie na czymś pozaempirycznym. Pojmowanie pozytywizmu, jako przeciwnego kierunkom prawno - naturalnym, jest doniosłe z punktu widzenia historycznego. Nie ma jednak głębszego znaczenia metafizycznego, chyba że chce się stwierdzić, że pozytywizm jest po prostu negacją prawa natury. Istotnie, jak wspomniano we wstępie, spora część podstawowych twierdzeń pozytywizmu ma charakter negatywny. Nie da się jednak nie zauważyć twierdzeń afirmujących (pozytywnych).

Pamiętając o różnicach zachodzących między pozytywizmem angielskim i francuskim, przejdźmy do problematyki faktów społecznych i prawnych. Należy uwzględnić, że z punktu widzenia pozytywizmu angielskiego, nie fakt prawny i społeczny, jako zewnętrzne i obiektywne zjawisko będzie analizowany, lecz wypowiedzi o tych zjawiskach formułowane w jakimś języku - najczęściej rzecz jasna w języku angielskim. Obszarem, w którym porusza się argumentacja za daną tezą, np. wyłącznej zależności faktów prawnych od faktów społecznych, jest obszarem analizy języka, w którym wypowiedzi są formułowane. W przypadku pozytywizmu francuskiego analizie będzie podlegało zjawisko zewnętrzne, np. utrwalony sposób zachowania człowieka wywołany przymusem.

funkcjonującą w doktrynie analogicznie do pozytywizmu „ogólnego”. Interesujące, że socjologia prawa rzadziej kojarzona jest z pozytywizmem, co świadczyć może o dominacji tradycji angielskiej.

26 Obu ogólnych terminów używam w celu skojarzenia wielu idei, a zatem metodycznie. Nie twierdzę, że istnieje przedmiot realny kryjący się za tymi pojęciami. Przeciwnie, $\mathrm{z}$ analiz wynika, że są to właściwie abstrakcje.

27 H.L. A. Hart, The Concept of Law, Oxford 2012, s. 185-193. 
Teza o społecznym źródle prawa współcześnie przedstawiana bywa m.in., jako twierdzenie, że fakty prawne ostatecznie wyznaczane są przez fakty społeczne. Kierunki prawnonaturalne mają opowiadać się za źródłowością płynącą również z faktów moralnych ${ }^{28}$. Jako że celem tego artykułu nie jest analiza sporu, istotne jest dostrzeżenie występujących w powyższym twierdzeniu tez natury metafizycznej. Po pierwsze, okazuje się, że mamy do czynienia $\mathrm{z}$ faktami prawnymi. Są one w relacji do faktów innego rodzaju, które możemy nazwać społecznymi. Istnieje zatem więź między nimi, która pozwala się domyślać, że jedne są w jakiś sposób zależne od drugich. Oczywiste wydaje się, że sposób rozumienia faktów społecznych determinuje rozumienie faktów prawnych. Fakty moralne miałyby być, przy uzasadnianiu prawa, konkurencyjne dla faktów społecznych, skoro różnica między dwoma kierunkami w filozofii prawa dotyczy właśnie tego, czy fakty moralne i społeczne, czy może tylko te drugie, wyznaczają fakty prawne. Takie ujęcie sprawy powoduje powstanie przeświadczenia, że oba nurty - pozytywistyczny i prawnonaturalny spierają się na tym samym poziomie argumentacji. Trudno poznać wszelkie argumenty jednej, jak i drugiej strony, jednak analiza metafizyczna doprowadza do wniosków, że z całą pewnością zachodzi różnica istotna.

Dochodzimy do zasadniczego punktu rozważań, który komplikuje dalszą analizę. Możemy bowiem pójść w dwóch kierunkach. Jeśli przyjąć, że istnienie relacji między faktami społecznymi i moralnymi, a prawnymi, jest tutaj decydujące, to wysiłki poznawcze zejdą z metafizycznego poziomu dyskusji, a przynajmniej go uszczuplą. Rezygnujemy wówczas z badania istnienia faktów społecznych, czegoś takiego jak fakt społeczny w ogóle, a przyjmując jego istnienie, próbujemy pokazać, że występuje on w relacji do faktu prawnego. Podobnie wygląda sprawa w przypadku kierunku opozycyjnego, przy czym miejsce faktu społecznego zajmie fakt moralny. Tymczasem właśnie to twierdzenie egzystencjalne - o istnieniu faktów społecznych, czy moralnych, jest kwestią sporną na poziomie metafizycznym. Następnie, zależne od niego twierdzenia esencjalne pozwalają dopiero na dojście do tego czy, i jakiego rodzaju relacja może występować. W tym znaczeniu pozytywizm prawniczy jest rzeczywiście kierunkiem dogmatycznym ${ }^{29}$. Okazuje się, że kierunki prawno-

28 T. Gizbert-Studnicki, op. cit., s. 21. Autor przywołuje w tym zakresie stanowisko Scott' a Shapiro.

29 Z punktu widzenia metafizyki klasycznej nie jest to bynajmniej obelga. Nie przeszkadza postawa dogmatyczna naukom przyrodniczym w odkryciu pewnej zależności, bez krytycznego rozbioru tez wyjściowych, np. sztandarowej - o istnieniu rzeczywistości. Chodzi zwyczajnie o umiejscowienie danego twierdzenia w ogólniej hierarchii twierdzeń. W starszej literaturze kwestia ta raczej nie budziła wątpliwości, skoro wykładana była w propedeutykach. Zob. H. Struve, Wstęp krytyczny do filozofii czyli rozbiór zasadniczych pojęć o filozofii, Warszawa 1898, s. 136-139. Jako że podręcznik powstał w czasach, w których zagadnienia podstawowe pozytywizmu były wciąż żywe, możemy tam odnaleźć kilka uwag na ten temat. Autor stwierdza, że dogmatyzm jest w pozytywizmie postrzegany, jako coś wstydliwego. Uwaga ta dotyczy również literatury polskiej tamtego okresu. Wynika stąd, 
naturalne, również mogą być w ten sposób odczytane. Celem zawężenia szerokiej problematyki, przyjrzyjmy się faktom społecznym w ich metafizycznym naświetleniu, pamiętając o różnicach zachodzących między angielską i francuską odmianą pozytywizmu.

\section{Teza społeczna pozytywizmu francuskiego}

W przywoływanym dziele Comte’a, poza ogólnymi tezami historiozoficznymi, odnajdujemy szereg tez dotyczących zagadnień społecznych. Okazuje się, że reprezentuje wspominany autor bardzo konkretny sposób ich rozumienia, znany metafizyce od czasów starożytnych. Otóż pozytywizm ma charakter możliwe najbardziej społeczny. Dzieje się tak dlatego, że społeczeństwo posiada swoistą bytowość ${ }^{30}$. Mamy zatem do czynienia z poglądem powołującym do istnienia byt społeczny, który jest rzeczywisty w tym sensie, że istnieje niezależnie od naszego ujęcia poznawczego (zatem realnie). Społeczeństwo, jako byt, po prostu istnieje. Odpierając możliwy zarzut ze strony krytyki, twierdzi autor, że sposób postrzegania społeczeństwa, jako bytu abstrakcyjnego (teza konkurencyjna), jest przestarzały, i wynika z nieobumarłego jeszcze do końca sposobu myślenia. Czytelnik może nabrać wątpliwości co do tego, czy aby na pewno Comte, zwalczając przecież zabobonne myślenie teologiczne i metafizyczne, powołuje do życia byt społeczny.

Nieco łagodzić tę interpretację może podanie uzasadnienia tego zabiegu. Comte wierzy, że pogląd o wzajemnej łączności społecznych relacji, spowoduje wzrost solidarności między ludźmi i lepsze dbanie o sprawy publiczne. Nie wartościując tego typu ideału, można stwierdzić, że jego motywacja jest inna niż poznawcza. W zasadzie jest ideologiczna, bądź polityczna, w zależności od rozumienia tych pojęć. Autor nie dlatego nadaje społeczeństwu bytowość niezależną, gdyż doszedł do takich wniosków prowadząc badania w celach poznawczych, lecz uznał, że taki pogląd zapewni najlepszą realizację wyznaczonych przez niego celów, w ostatniej (pozytywnej) fazie rozwoju. Ostatecznie posuwa się Comte do twierdzenia, że człowiek, w ścisłym znaczeniu, nie istnieje, lecz istnieje Ludzkość. Twierdzi to z punktu widzenia rozwojowego - bez społeczeństwa rozwój człowieka jest niemożliwy ${ }^{31}$. Jak się wydaje, to jest właśnie zasadnicze twierdzenie metafizyczne, którego dotyczył spór toczony u jego zarania. Przy okazji jest to jedna $\mathrm{z}$ tez uzasadniająca na poziomie filozoficznym, funkcjonującą na poziomie ideologicznym i praktycznym, doktrynę socjalistyczną.

że niechęć pozytywizmu w stosunku do dogmatyki musi być motywowana inaczej niż poznawczo (inaczej niż filozoficznie, naukowo), np. religijnie, co nie jest, uwzględniając biografię Augusta Comte'a, wcale zadziwiające.

30 A. Comte, op. cit., s. 87.

31 Ibidem, s. 87-88. 
Przy rozbiorze powyższych twierdzeń okazuje się, że metafizyka jest obecna. Daje się jednak zauważyć, że autor nie tylko deklarował do niej niechęć, lecz skutecznie stosował się do swoich deklaracji w tym zakresie. Odniesienia do poruszanych zagadnień można bowiem znaleźć już u Arystotelesa, który zastanawiał się w Metafizyce $e^{32}$ nad pierwszeństwem bytu całości i jego stosunku do części. Podobnie będzie przy zagadnieniu sposobu istnienia idei Platona, a także $\mathrm{w}$ sporze o uniwersalia, gdzie przecież kluczowym zagadnieniem było to, w jaki sposób istnieją powszechniki ${ }^{33}$. Biorąc pod uwagę tylko powstałe w tamtym czasie stanowiska stajemy przed wieloma możliwymi punktami widzenia. Comte nie chce jednak sięgać do zamierzchłej przeszłości. Zadowala się twierdzeniem, że zagadnienia te są już nieaktualne i nie przystają do obecnej fazy rozwoju. Jest to wniosek wyprowadzony z jego historiozoficznych zapatrywań, a nie z tego, jak się rzeczy miały w ich historycznym rozwoju. Warto zauważyć, że snucie wizji na temat rozwoju ludzkości, przez poszczególne etapy, celem dojścia do pewnego ideału, w tym przypadku pozytywnego, jest czymś niemal powszechnym w XIX-wiecznej filozofii ${ }^{34}$. Co ciekawe, jest to domena filozofów idealistów, zwłaszcza niemieckich, których Comte uważa za metafizyków, i od których postanawia się odciąć. Paradoksalnie, lecz nie bezzasadnie, można stwierdzić, że wywód Comtéa jest w tym zakresie dowolny, a sam autor ponadto reprezentuje wysoki poziom ignorancji i brak wiedzy na temat zasadniczych problemów filozoficznych, czego zresztą nie omieszkano mu dosadnie wytknąć i udowodnićs ${ }^{35}$.

Raz przyjąwszy tezę, że społeczeństwo jest bytem istniejącym samoistnie, a nie przykładowo abstrakcją, musimy podążać jej śladem. W połączeniu z roszczeniem Comte’a co do konieczności aplikacji metod wiedzy przyrodniczej do humanistyki (wymóg pewności), rysuje się obraz ogromnego przedsięwzięcia. Próba ta nazwana została socjologią (fizjologią społeczną) i dała podwaliny do rozwoju nowej dziedziny wiedzy. Rozpatrując tę wyjściową tezę pozostajemy na poziomie dyskusji metafizycznej. W innym przypadku zachodzi ryzyko nieporozumienia i pomieszania poziomów argumentacji. Widać to dokładnie na przy-

32 Arystoteles, Metafizyka, tekst pol. oprac. M. A. Krąpiec, A. Maryniarczyk, na podstawie tłum. T. Żeleźnika, Lublin 2017, s. 696-697.

33 Zob. S. Swieżawski, Dzieje europejskiej filozofii klasycznej, Warszawa - Wrocław 2000, s. 454-459.

34 Interesującą próbę tego sposobu myślenia można spotkać także w polskiej literaturze filozoficznoprawnej XIX wieku. Zob. J. Niemirycz, Filozofja historji prawa, Warszawa 1874. Praca zawiera bogaty zasób informacji historycznych, lecz najbardziej uwagę zwraca jej tytuł. Historycznie zagadnienie to jest jeszcze starsze, a zasadnicze prace na tym polu poczynił już św. Augustyn w Państwie Bożym. Perspektywa jest inna, cel również, jednak mechanizm pozostaje niezmienny. $\mathrm{Z}$ tej perspektywy, postulaty Comte’a nie przedstawiają się, jako odkrywcze. Ponownie można odnieść wrażenie, że o filozofię, a tym bardziej metafizykę, w pozytywizmie nie chodzi.

35 Zob. H. Struve, op. cit., s. 285-305. Autor zebrał najważniejsze zarzuty wystosowane przeciwko twierdzeniom Comte’a, które opatrzył szczegółową bibliografią obejmującą kilkadziesiąt pozycji zarówno pro, jak i contra. Wynika stąd druzgocąca dla Comte’a opinia o jego merytorycznym przygotowaniu do głoszenia tez, które formułował. Docenia się jednak jasne postawienie kwestii metodycznych i sformułowanie założeń dających podwaliny pod budowę nowych dyscyplin. 
kładzie zagadnienia faktów społecznych. Jako że społeczeństwo, a zatem także Ludzkość, nie są dostępne w całości naszemu poznaniu empirycznemu (tak jest również współcześnie), konieczne staje się zawężenie przedmiotu badań. Społeczeństwo przechodzi do sfery nieuchwytnej, niedostępnej esencjalnie i w takim potocznym sensie jest ono bytem metafizycznym. Domyślamy się jego istnienia na zasadzie istnienia ogółu w szczególe. W ten sposób człowiek (jednostka) staje się egzemplarzem społeczeństwa i „nosicielem” jego swoistej bytowości. Być może również i taki pogląd na pozycję człowieka ma zapewnić obiektywność twierdzeniom socjologicznym.

\section{Teza społeczna pozytywizmu angielskiego}

Jeśli chodzi o kwestię rekonstrukcji założenia metafizycznego leżącego u podstaw pozytywizmu prawniczego angielskiego, to zasadniczo pokrywa się ona z głównymi tezami ogólnego pozytywizmu angielskiego. Społeczeństwo jest pojęciem, które wyrażane $\mathrm{w}$ określonym języku może podlegać badaniu, jako samoistny przedmiot ${ }^{36}$. W tym metodycznym ujęciu brakuje „łącznika”, swoistego przejścia do zagadnień rzeczowych. Trudność tę filozofia analityczna dzieli z idealizmem w ogóle, dlatego też ustalenie sposobu rozumienia społeczeństwa nastręcza w tym przypadku większych trudności ${ }^{37}$. Wydaje się, że podejście językowe jest wtórne w tym sensie, że analizuje wypowiedzi już wyrażone, które z kolei powstały w oparciu o założenia metafizyczne. Mielibyśmy zatem do czynienia z rozważaniami językowymi, jako „meta” - rozważaniami i to byłoby ich zasadnicze metafizyczne rozumienie ${ }^{38}$. Jeśli zatem pozytywizm prawniczy angielski nie chciałby być metodą tylko krytyczną, zmuszony jest do „wyjścia poza” podmiotowość, w tym przypadku poza język, utożsamiony ze świadomością. $\mathrm{W}$ takim razie może zasadniczo albo język usamoistnić - analogicznie jak Comte społeczeństwo, albo też próbować posiłkować się ustaleniami rzeczowymi, jednak za cenę rezygnacji z kardynalnego założenia. Ostatecznie musi uznać istnienie i możliwość poznania bytów pozapodmiotowych, wracając do problemu relacji języka, jako narzędzia poznawczego, do rzeczy poznawanej.

36 W literaturze przedmiotu wyróżnia się pozytywizm pierwotny, który wiąże się z postaciami J. Bentham’a i J. Austin’a. Nastawienie anty-metafizyczne jest wspólne również na poziomie rozważań prawniczych. Zob. M. Zirk-Sadowski, Analityczna filozofia prawa..., s. 47.

37 Tak jak Kant, nie może dotrzeć do „rzeczy samych w sobie” i poprzestaje na ujęciach poznawczych, zamykając całość $\mathrm{w}$ rozumie teoretycznym, podobnie i obranie za przedmiot analizy języka, jako empirycznie dostępnego wyraziciela owych pojęć, nie pozwala przekroczyć jego ram. Filozof Królewiecki ucieka się do konstrukcji rozumu praktycznego i w ten sposób próbuje uzasadniać, np. powinność. Niemniej jednak raz wprowadzony dualizm rzutuje na dalszą myśl.

38 M. Zirk-Sadowski, Analityczna filozofia..., s. 49. Postępowanie to wymaga uznania tożsamości sfery poznawczej i językowej. Inaczej niemożliwe jest uczynienie języka samodzielnym przedmiotem badawczym, jeśli punktem wyjścia było rozróżnienie świadomości i jej wyrażenia za pomocą języka. 
Powstaje w związku z tym pytanie, co mają na myśli przedstawiciele pozytywizmu prawniczego, kiedy mówią o społeczeństwie? Jeśli zasadniczo dwa wspomniane ujęcia, to znaczyłoby to, że pozytywizm prawniczy jest istotnie pozytywizmem ogólnym, w odpowiedniej wersji - angielskiej albo francuskiej. Przedmiot jego zainteresowania byłby wówczas szczególny - prawo. Jeśli okazałoby się natomiast, że z tez filozofów prawa można wyprowadzić inne niż przytoczone twierdzenia metafizyczne, co do bytowości społeczeństwa, wówczas należałoby zbadać, czy można je uznać za charakterystyczne dla twierdzeń metafizycznych pozytywizmu.

\section{Problematyka faktu społecznego}

W odniesieniu do pozytywizmu francuskiego, ograniczę się do sposobu rozumienia „faktu społecznego” przez E. Durkheim’a. O tym, że wprowadzone pojęcie budziło liczne kontrowersje, możemy dowiedzieć się już ze wstępu do wydania drugiego dzieła Zasady metody socjologicznej. Autor, odrzucając zarzut materializmu, posługuje się analogią. Twierdzi mianowicie, że fakty społeczne, nie będąc rzeczami materialnymi, są rzeczami na tej samej zasadzie, jednak $\mathrm{w}$ różny sposób $\mathrm{b}^{39}$. Jest to bardzo istotne twierdzenie. Po pierwsze, dlatego, że zwraca uwagę na metodę, sposób interpretacji zjawiska, a po drugie dlatego, że podkreśla trudność w „dotarciu” do faktów. Niemniej jednak stwierdza Durkheim ich istnienie, choć wydaje się, że musimy je metodycznie odkrywać.

Jako przykład trudności $\mathrm{z}$ rekonstrukcją metafizycznych podstaw tej tezy może posłużyć kwestia typów postępowania i myślenia. Są one, zdaniem Durkheim’a, wobec jednostki zewnętrzne. Zawdzięczają swoje istnienie przymusowi - sile, dzięki której narzucają się jednostkom. Nie respektują zatem wyrażenia woli w tym zakresie ${ }^{40}$. Istnienie (wymiar egzystencjalny) typów postępowania i myślenia jest zależny od istnienia przymusu, natomiast jest niezależny od woli jednostek. Znajdujemy zatem potwierdzenie, na poziomie szczegółowym, tezy Comte’a o samoistności społeczeństwa. Pamiętajmy jednak, że w przykładzie tym nie o fakty społeczne chodzi. Fakty społeczne dopiero „polegają na” sposobach działania i myślenia ${ }^{41}$. Czyni to je jeszcze trudniejszymi do uchwycenia.

W ostatecznej definicji „faktu społecznego” Durkheim podkreśla jego: dynamiczność, zdolność do wywierania przymusu, samodzielne istnienie, które obja-

39 E. Durkheim, Zasady metody socjologicznej, Warszawa 2000, s. 7. Autor odpowiada na zarzuty krytyki wobec zaproponowanego sposobu rozumienia "faktu społecznego". Precyzuje, że nie ma na myśli istnienia faktów, jako rzeczy materialnych. Posługuje się do tego celu analogią. Jest to istotne o tyle, że jednym z zarzutów wobec pozytywizmu w ogóle było to, że jest on ukrytym materializmem. Apologia zmierza w takim kierunku, że owszem wielu pozytywistów materialistami było, jednak można być pozytywistą, materialistą nie będąc. Zob. F. S. Krupiński, op. cit., s. 49.

40 Ibidem, s. 28.

41 Ibidem, s. 30 . 
wia się m.in. w jego niezależności od jednostkowych przejawów ${ }^{42}$. Dostrzegamy ponownie zgodność z podstawowym twierdzeniem metafizycznym Comte'a o społeczeństwie. Przejawia się ona przede wszystkim, w kluczowej dla zrozumienia problemu tezie, o samoistnej bytowości społeczeństwa. Rola jednostki zostaje w sensie bytowym umniejszona, sprowadzona w zasadzie do czegoś, co można określić, jako bycie przedmiotem objawiania się (działania) bytu społecznego. Niezależność faktów społecznych zostaje przez Durkheim’a spotęgowana do tego stopnia, że nie wyczerpują się one w praktyce działania - stosowaniu przez poszczególnych ludzi. Mogą one bowiem istnieć również w przypadku ich niestosowania ${ }^{43}$. Autor podaje jeszcze szereg innych okoliczności mających ułatwić czytelnikowi zrozumienie, czym są fakty społeczne, wydaje się jednak, że zasadnicze momenty zostały już przedstawione.

Możemy dostrzec, że celem Durkheim’a jest rzeczywiście spełnienie pozytywistycznego wymogu oparcia wniosków na obiektywnej podstawie - fakcie. Aplikuje on metodę do badania społeczeństwa i w tym właśnie celu musi odnaleźć odpowiedni przedmiot badawczy. Przyjmuje tezę, zgodną z poglądem Comte’a, że społeczeństwo jest bytem samoistnym, pierwotnym w stosunku do jednostki. Odcina się tym samym od jednego $z$ innych możliwych rozstrzygnięć tego zagadnienia, a czyni to pośrednio, negując ograniczenie istnienia faktu społecznego, do momentu działania przez jednostki. Wydaje się, że nie ma innej możliwości, jak tylko uznać, że społeczeństwo istnieje własnym istnieniem, a jednostki istnieniem zależnym od bytu pierwszego, jako że to w nich przejawia się jego istnienie. Obiektywizm, tym razem rozumiany jako opozycja do kierunków podmiotowych, przejawia się w zwróceniu uwagi na przymusowość faktów, na ich zewnętrzność ( $w$ sensie wolicjonalnym). Jest to moment ważny z punktu widzenia problematyki prawniczej ${ }^{44}$.

Próba konstrukcji faktu prawnego na tym gruncie musi istotnie respektować charakter bytowy faktu społecznego. Obiektywne zorientowanie pozytywizmu francuskiego ogranicza powstanie trudności charakterystycznych kierunkowi podmiotowemu. Zasadniczo fakt prawny jest jednym z faktów społecznych. Zawiera się metafizycznie $w$ fakcie społecznym. Jeżeli wiemy, czym jest fakt społeczny, to wiemy czym jest fakt prawny. Uwzględniając element przymusowości, można powiedzieć, że fakt prawny byłby wybitnie faktem społecznym. $\mathrm{Z}$ tej perspektywy kwestia uzasadnienia metafizycznego faktu prawnego, a zatem prawa, nie budzi szczególnych kontrowersji. Posiłkując się analogią, można

42 „Nasza definicja obejmie tedy cały przedmiot definiowany, jeśli powiemy: Faktem społecznym jest wszelki sposób postępowania, utrwalony lub nie, zdolny do wywierania na jednostkę zewnętrznego przymusu; albo inaczej: taki, który jest $\mathrm{w}$ danym społeczeństwie powszechny, mający jednak własną egzystencję, niezależną od jego jednostkowych manifestacji”. Ibidem, s. 41.

43 Ibidem, s. 35.

44 Ponownie należy zaznaczyć różnice $\mathrm{w}$ rozumieniu psychologii w obu odmianach pozytywizmu. Zob. S. Pawlicki, op. cit., s. 110. 
wyprowadzić odpowiednie wnioski w tym zakresie. Socjologia prawa, jako nauka szczegółowa, nie podejmowałaby wówczas metafizycznych rozważań na temat społeczeństwa, a zakładając, w zależności od konkretnej szkoły, jeden ze sposobów rozumienia społeczeństwa i faktu społecznego, wyprowadzałaby szereg dalszych wniosków.

Inaczej przedstawia się rzecz w przypadku pozytywizmu angielskiego. Jako przykład może posłużyć sposób rozumienia metafizyki przyjmowany przez Herberta Harta. Zaznaczyć należy, że rekonstrukcja podstaw poglądu autora The Concept of Law, wynika z tradycji myśli starszej, niż wiek XIX. Możemy to zaobserwować precyzyjnie na problemie relacji prawa do moralności. Koncepcja prawa natury związana jest, zdaniem Harta, z wizją świata przed-nowożytną. Charakteryzuje się przekonaniem, że świat urządzony jest teleologicznie, a rzeczy zmierzają do właściwych im celów. Posiadają różne stopnie doskonałości, a zatem istnieje określona hierarchia rzeczywistości. Stanowisko nowożytne dostrzega jedynie występujące zdarzenia i towarzyszące im regularności. Z tej perspektywy postąpić w nauce, oznacza tyle, co poznać te regularności ${ }^{45}$.

Możemy zaobserwować szereg inspiracji filozoficznych twierdzeń Harta. Nie bez znaczenia będzie rozumienie zasady przyczynowości u Hume’a, a także twierdzenia psychologiczne tegoż autora. Poznawanie rzeczywistości jest czynnością abstrakcyjną. Weryfikowalność tez, owych regularności, odbywa się poprzez zestawienie z tymi regularnościami, a zatem jest wyjściem poza sferę podmiotową.. Sztandarowa kwestia przedmiotu ludzkiego poznania pozostaje zatem otwarta. Kwestia tego, o jaką metafizykę Hartowi chodzi, jest trudna do odgadnięcia. Już Arystoteles rozróżniał przecież twierdzenia przynależne do porządku fizycznego i metafizycznego ${ }^{46}$. Za błąd poczytane może być przeniesienie twierdzeń metafizycznych do fizyki, a właściwie zrozumienie twierdzenia metafizycznego, jako fizycznego. Wówczas jednak metafizyka pozostaje nietknięta, a sprostować należy jedynie to przesunięcie, pomieszanie. Choć omawiany autor odwołuje się zarówno do Stagiryty, jak i Tomasza z Akwinu, to pozostaje w kontekście rozważań o celowości i nie rozumie ich metafizycznie, lecz raczej etycznie, jako cel dążenia człowieka. Widzimy zatem, że rozważania metafizyczne, jako abstrakcyjne w stopniu możliwe dla człowieka najwyższym, są bardzo

45 H.L. A. Hart, op. cit., s.188-90. Istnienie dobra, jako celu pożądania, przedstawia się w przypadku wizji teleologicznej, jako istniejące w rzeczy. Nie jest pożądane dlatego, że człowiek tak chce, lecz przeciwnie, jest dobre i dlatego jest pożądane. Por. H. Hart, T. Honoré, Causation in The Law, Oxford 1985, s. 10-13. Na różne stanowisko filozofii analitycznej w stosunku do metafizyki, w zależności od okresu i konkretnej szkoły, wskazuje T. Szubka, Metafizyka w filozofii analitycznej, Lublin 1995, s. 9-29. Obecność w przygotowanej antologii tekstów problematyki realizmu wskazuje, że przedstawiciele filozofii analitycznej sami uważają te zagadnienia za fundamentalne.

46 Nie chodzi o termin „metafizyka”, jako że ten nie jest autorstwa Stagiryty, lecz o czynność poznawczą, która się za nim kryje. 
trudno uchwytne. Ważne, że Hart rezygnuje z definicji per genus proximum et differentia specifica. Zamiast tego uważa prawo za zjawisko złożone, które można rozpatrywać na wielu płaszczyznach. W ten sposób częściowo omija metafizyczną trudność ${ }^{47}$.

Wracając do rozważań głównych, możemy zauważyć, że każdorazowo, gdy Hart wspomina o prawie, mówi o jego pojęciu ${ }^{48}$. Tytuł taki nosi też całość pracy autora. Nie jest pedanterią zwrócenie uwagi na ten właśnie fakt, jako że wspominaliśmy, iż zasadniczo tego dotyczy spór na poziomie metafizycznym. Prawo jest dla Herberta Harta przede wszystkim pojęciem. Nie wydaje się, żeby rozumiał to twierdzenie ściśle, ponieważ widzieliśmy, że tezy można weryfikować poza podmiotem - w regularnościach, które, istnieją poza sferą podmiotową. Mamy do czynienia albo z celową niekonsekwencją, która wynikać może z bardzo różnych przyczyn, również z typowo praktycznego nastawienia, albo też z faktyczną realizacją założeń Comte’a w zakresie filozofii pozytywnej i metafizyki ${ }^{49}$. Zawsze bowiem, posługując się klasycznym definiowaniem, które zostało odrzucone, możemy zapytać, czym jest to „prawo”, które przejawia się w wielu dziedzinach. Czy jest ono jedynym zjawiskiem złożonym, czy istnieją też inne? Jeśli tak, to co je wyróżnia na tle pozostałych? Pominięcie tych trudności wydaje się realizować postulat pozytywizmu, jakim jest słynne ignoramus.

Potwierdzeniem tego, że nie o rzeczy i relacje między nimi chodzi, lecz o ich sposoby poznawcze, jest sformułowanie, że pozytywizm prawniczy to teoria analityczna ${ }^{50}$. Skoro zarówno fakt społeczny, jak i fakt prawny, są pojęciami, to odpowiedź metafizyczną mamy zasadniczo gotową. Jako będące jakościowo tym samym (bytowo są to pojęcia) stają się problemowe w ustaleniu wzajemnych relacji. Pozostają zatem kryteria inne niż jakościowe. Patrząc na zagadnienie z punktu widzenia metafizyki klasycznej, sprawa przedstawia się zaskakująco. Poszukując uzasadnienia faktu prawnego w fakcie społecznym, poszukujemy uzasadnienia pojęcia w pojęciu. Z pomocą może przyjść zastosowanie kryterium dodatkowego, jakim jest w tym przypadku aspekt ilościowy. Możemy przykładowo stwierdzić, że jedno pojęcie jest ogólne, a drugie szczegółowe (w sensie ilościowym - istnienia desygnatów). Pozostajemy jednak cały czas na poziomie

47 Ibidem, s. 16-17.

48 J. Stelmach, R. Sarkowicz, Filozofia prawa XIX i XX wieku, Kraków 1998, s. 23-24, 36. Autorzy zwracają uwagę na metodologiczne nastawienie Harta, który nie odpowiada na pytanie „czym prawo jest?”, lecz zastanawia się nad tym, „jaką pełni ono funkcję językową?”. Problematyczność uzasadnienia, na jakiej podstawie można będzie przejść następnie do tezy metafizycznej, a zatem odpowiedzi na pytanie „czym jest prawo?”, pozostaje nierozstrzygnięta.

49 T. Gizbert-Studnicki, op. cit., s. 20. Autor, spośród dwóch tez charakterystycznych dla pozytywizmu: a) o separacji prawa i moralności, b) o społecznych źródłach prawa, jako pojęciową określa tylko pierwszą z nich. Bytowy charakter społecznego pochodzenia prawa wydaje się sprawiać w pozytywizmie prawniczym angielskim większe trudności.

50 Ibidem, s. 24. 
zależności pojęciowej. Bytowo, a zatem w sensie metafizycznym, pozostajemy na tym samym stanowisku. Czymś drugoplanowym jest sposób określenia relacji między pojęciami, skoro nie ma podstawy jakościowo innej niż one same $e^{51}$ Czym byłaby owa zachodząca relacja, bądź sposób uznania, jeśli nie naszym pojęciem?

\section{Podsumowanie}

Stosowanie metafizyki do zreflektowanego namysłu nad prawem, jest stosunkowo mało popularne. Jeśli połączyć to stwierdzenie z twierdzeniem o nieusuwalności metafizyki, to okazuje się, że temat jest nie tylko sam w sobie trudno uchwytny, ale dodatkowo konieczny do analizy, gdyż rzadko wyrażany wprost.

Wydaje się, że postawa pozytywistyczna w stosunku do filozofii, jest zasadniczo przyjmowana również współcześnie w dwóch wyszczególnionych wariantach: francuskim i angielskim. Należy zwrócić uwagę, że pozytywiści metafizykę konstruują. Jest to pozycja raczej aktywna niż pasywna. $Z$ analiz wynika, iż metafizyka, do jakiej uprzedzeni byli pozytywiści francuscy, jest nowożytną wersją filozofii podmiotu. Akceptuje takie ujęcie pozytywizm angielski. Skutkuje to zawężeniem pola manewru do analizy bytów myślnych, jak jest to w przypadku szkoły analitycznej, albo do prób konstrukcji bytów abstrakcyjnych i przypisywania im istnienia realnego - pozytywizm francuski. Echa obu fundamentalnych twierdzeń przekładalne są w stopniu znacznym na tzw. pozytywizm prawniczy. Taka sytuacja możliwa jest do zaobserwowania głównie we wstępnych fazach rozwoju obu nurtów. Należy podkreślić, że znajomość metafizyki klasycznej, a zatem również z czasów przed Kartezjuszem, Hume’m i Kantem, jest niewielka. Widoczna jest już na etapie niedostrzegania różnicy między twierdzeniami metafizycznymi i fizycznymi.

Współcześnie mamy raczej do czynienia z eklektyzmem metafizycznym i metodologicznym ${ }^{52}$. W związku $\mathrm{z}$ tym trudno jest jednoznacznie stwierdzić, jakie twierdzenia poszczególni autorzy przyjmują. Raczej dominuje postawa nie przyjmowania sztywno definicji, lecz traktowania twierdzenia, jako propozycji $\mathrm{w}$ dyskursie. Wydaje się, że taka postawa, również ma określone uzasadnienie metafizyczne, jednak jego analiza wykracza poza ramy niniejszego artykułu.

Interesujący wydaje się fakt, że bez względu na zajmowane stanowisko, metafizyka zawsze będzie obecna. Jeszcze ciekawsze jest to, że chodzi o metafizykę najdawniejszą, zapoczątkowaną przez Arystotelesa. Być może już samo to świadczy o jej uniwersalności. Oparta na podstawie realistycznej, pozwala trwać mimo

51 Ibidem, s. 28. Wprowadzane jest również pojęcie „rzeczy”, jednak nie ma pewności, czy nie jest to aby „pojęcie” rzeczy.

52 L.J. Żukowski, Prawo jako fakt społeczny, „Studia Prawnicze” 2017, z. 1(209), s. 7-22. 
upływu wieków, a także pozwala podejmować jej tezy niezależnie od warunków miejsca i czasu. Widać to najlepiej na przykładzie problemów, jakie są kluczowe do rozstrzygnięcia dyskutowanych w niniejszym artykule kwestii. Wszystkie odnaleźć można w Metafizyce Arystotelesa. Są to zagadnienia: realizmu ludzkiego poznania, dualizmu i monizmu poznawczego, a także istnienia bytów myślnych, pierwotności i wtórności bytów - a w tym, stosunku części do całości. Wieszczony już przed laty przez Comte’a i jego następców postęp, nie sprawił, aby kwestie te stały się nieaktualne. Mimo stanowczych twierdzeń opozycjonistów, nie można problemów tych uznać za należące do koniecznego, ale słusznie minionego okresu rozwoju ludzkości.

\section{Bibliografia}

Arystoteles, Metafizyka, tekst pol. oprac. M. A. Krąpiec, A. Maryniarczyk, na podstawie tłum. T. Żeleźnika, Lublin 2017.

Bekrycht T., Metafizyka pozytywizmu prawniczego wświetle fenomenologii prawa, „Avant. The Journal of the Philosophical-Interdisciplinary Vanguard" 2018, t. 9, nr 1.

Comte A., Rozprawa o duchu filozofji pozytywnej, Warszawa 1936.

Czeżowski T., O metafizyce, jej kierunkach i zagadnieniach, Kęty 2004.

Durkheim E. zasady metody socjologicznej, Warszawa 2000.

Firlej M., Założenia metafizyczne w programie pozytywizmu logicznego, „Hybris” 2016, nr 35B.

Gizbert-Studnicki T., Metafizyka pozytywizmu prawniczego, „Principia” 2015, t. LXI-LXII.

Hart H.L.A., The Concept of Law, Oxford 2012.

Hart H.L.A., Honoré, T., Causation in The Law, Oxford 1985.

Kaszewski K., Pozytywizm, jego metoda i nastęstwa, brw.

Krupiński F.S., Szkoła pozytywna, Oddruk z Bibl. Warsz. z m. lipca, sierpnia i września 1868.

Leksykon współczesnej teorii i filozofii prawa, red. J. Zajadło, Warszawa 2007.

Maryniarczyk S., Metafizyka a ontologie. Próby przezwyciężania metafizyki i ich paradoksy, Lublin 2015.

Mazurkiewicz Sz., Legal Positivism Social Source Thesis and Metaphysical Grounding: Employing Metaphysical Grounding Based on Metaphysical Laws, „Archiwum filozofii prawa i filozofii społecznej" 2019, nr 2.

Niemirycz J., Filozofja historji prawa, Warszawa 1874.

Ogonowski Z., Filozofia szkolna w Polsce XVII wieku, Warszawa 1985.

Pawlicki S., Studya nad pozytywizmem, Warszawa 1886.

Reinstadler S., Elementa philosophiae scholasticae, Fryburg Bryzgowijski 1901.

Stelmach J., Sarkowicz, R., Filozofia prawa XIX i XX wieku, Kraków 1998. 
Strawson P., Analiza i metafizyka, Kraków 1994.

Stróżewski W., Ontologia, Kraków 2004.

Struve H., Wstęp krytyczny do filozofii czyli rozbiór zasadniczych pojęć o filozofii, Warszawa 1898.

Taine H., Filozofia pozytywna w Anglii. Studyum nad Stuartem Millem, Warszawa 1883. Wprowadzenie do nauk prawnych. Leksykon tematyczny, red. A. Bator, Waszawa 2012. Zirk-Sadowski M., Analityczna filozofia prawa, [w:] Filozofia prawa. Normy i fakty, red. J. Hołówka, B. Dziobkowski, Warszawa 2020.

Zirk-Sadowski M., Pozytywizm prawniczy a filozoficzna opozycja podmiotu i przedmiotu poznania, [w:] Studia z filozofii prawa, red. J. Stelmach, Kraków 2001.

Żukowski L. J., Prawo jako fakt społeczny, „Studia Prawnicze” 2017, z. 1 (209).

\section{StreszCZENIE}

\section{Problematyczność stosowania metafizyki do pozytywizmu prawniczego na przykładzie tezy o społecznym źródle prawa}

Negacja metafizyki w pozytywizmie wynika z rozumienia jej w duchu Augusta Comte'a, czyli jako minionej fazy rozwoju historycznego ludzkości, bądź jako idealistycznej filozofii niemieckiej XIX w. Z historycznego punktu widzenia, metafizyka ma rodowód znacznie starszy i niezależnie od okresu rozwoju, jej problematyka była stale podejmowana na przestrzeni wieków. Nie tylko pozytywizm może oceniać metafizykę, lecz możliwa jest także ocena zwrotna. Analiza pozytywizmu prowadzi do wniosku, że termin ten używany jest na oznaczenie zasadniczo dwóch różnych nurtów: francuskiego i angielskiego. Podział ten daje się zastosować do filozofii prawa, gdzie wyróżnić możemy odpowiednio szkołę: socjologiczną i analityczną. Perspektywa klasycznej metafizyki, skoncentrowana na zagadnieniach bytowych, dostrzega zależność tez pozytywizmu prawniczego od zapatrywań na status bytowy przedmiotu, który dana szkoła przyjęła. W przypadku pozytywizmu francuskiego jest to zasadniczo twierdzenie o społeczeństwie, jako bycie ogólnym, istniejącym niezależnie od jednostek (człowieka). W przypadku pozytywizmu angielskiego odpowiedź na to pytanie ogranicza się głównie do analiz wypowiedzi na temat społeczeństwa, a zatem analizy podmiotowych ujęć poznawczych - konkretnie języka. Dwa wyszczególnione ujęcia nie są wyczerpujące. Absolutyzująca postawa jest szkodą dla pełnej perspektywy badawczej. Zorientowane praktycznie nauki prawne, przyjmując wypracowane koncepcje, wikłają się w analogiczne trudności do tych, jakie powstały na ogólnym poziomie filozoficznym. 


\section{SUMMARY}

\section{The problem of applying metaphysical explanation to legal positivism on the example of social source thesis}

The denial of metaphysics in positivism is a result of ideas proposed by August Comte, who considered metaphysics either as an outdated way of understanding reality characteristic to previous stages of human development, or as idealistic German philosophy of XIX-century. From deeper historical perspective, metaphysics is much older and its problems can be taken under consideration independently of development of sciences. Not only positivism can make statements on metaphysics. Reversed activity is both possible and necessary. Analysis of positivism leads to the conclusion that this term is used to indicate two fundamentally different schools of thought: French and English. This division can be applied to philosophy of law, where we can analogically divide between sociological and analytical school of law. Classical metaphysical perspective is focused on ontological issues and recognizes connection between positivism and legal positivism, which is based on the ontological status of the object of consideration. In the case of French positivism, it is general statement that society exist independently of human beings and their activities. English version of positivism is limited to the question of how the term "society" functions in language and in that sense seems to be subjective - limited to language as an independent epistemic object. Both proposed concepts ignore the fact that wider perspective is possible. Acceptance of absolute point of view leads to ignorance about philosophical approach to the subject. Practically oriented legal disciplines, adopting results of theory, share analogical difficulties as those present at philosophical level. 